\title{
INTERGROUP RUDENESS AND THE METAPRAGMATICS OF ITS NEGOTIATION IN ONLINE DISCUSSION FORA
}

\author{
Sonja Kleinke and Birte Bös
}

\begin{abstract}
This study investigates the communicative practices in English and German online discussion fora as exemplified by two thematically related sample threads. Combining first- and second-order approaches to (im-)politeness, the paper focuses on the question of how participants use intergroup rudeness as a means of in- and outgroup construction and examines how intergroup rudeness is metapragmatically negotiated as the discussions unfold. The results show that intergroup rudeness as well as metapragmatic comments are handled very differently in the two communities explored. Suggesting cultural preferences, there is a much higher degree of interactivity and a clear preference for negotiation at an interpersonal level in the German discussion group; its English counterpart favours negotiation at an intergroup level. Both threads provide metapragmatic evidence that the frequent use of rudeness tokens does not automatically make rudeness an accepted norm. ${ }^{1}$
\end{abstract}

Keywords: Intergroup rudeness; Metapragmatic utterances; Impoliteness; Politeness; First- and secondorder (im-)politeness.

\section{Introduction}

In recent years a significant amount of research has been done on Internet discussion fora (e.g., Largier 2002; Marcoccia 2004; Maricic 2005; Tanskanen 2007; Angouri \& Tseliga 2010; Kleinke 2010). What renders them particularly interesting is their dynamic nature as self-organising communities in which individual and group identities as well as communicative norms are displayed and negotiated. Rudeness figures prominently in many of these fora. Especially in online fora on political topics, the specific conditions of public message boards blend with the more general framing conditions of discussions. Not only are these asynchronous, polylogal, and usually anonymous in character, they are also extensive and display a high degree of emotional involvement. In order to spark discussion, topics are often intentionally controversial

${ }^{1}$ We would like to thank the editors of this special issue (Miriam Locher, Brook Bolander, Nicole Höhn) and Susan Herring as well as the anonymous reviewers for their constructive comments on previous versions of this paper. 
and thus inspire mild to strong forms of disagreement (cf. Kleinke 2007, 2010, 2012; Angouri \& Tseliga 2010).

In this paper, we focus on how rudeness is related to the process of group construction and negotiation. Comparing an English and a German sample thread, this study investigates which linguistic tokens participants use in their performance of intergroup rudeness, how the appropriateness of such tokens is negotiated, and how they contribute to the construction of in- and outgroups within the respective fora. In this way, this study aims to extend the conceptualisation of 'intergroup rudeness' and to find out more about the forum- and possibly culture-specific nature of intergroup rudeness and its metapragmatic negotiation.

In this context, rudeness is defined in line with Culpeper's (2010: 3233) notion of 'impoliteness' as a term applying to both a culturally shaped negative evaluation of certain types of situated behaviours and "specific behaviours occurring in specific contexts" (possibly intentionally) triggering such negative evaluative attitudes, "because they cause or are presumed to cause offence". Following Culpeper, we assume that behaviours are subject to being viewed as impolite or rude "when they conflict with how one expects them to be, how one wants them to be and/or how one thinks they ought to be" (Culpeper 2010: 3233). This delineates 'rudeness' in the sense we are using the term from cases of 'accidental rudeness' (Bousfield 2008) and also from unmarked 'politic behaviour' which is "in line with the norms established in previous interactions" (Watts 2005: xIiii). 'Rudeness' thus includes much of what is captured by Bousfield (2008) and Locher and Watts (2008) as 'impolite'.

The ubiquity of rudeness tokens has often been linked to the anonymity of Internet discussion fora and public Internet communication in general (Suler 2004; Maricic 2005; Kleinke 2007; Johnson 2010; Danet 2013). However, social psychological research into the effects of anonymity in computer-mediated discourse (CMD) yields "surprisingly variable" results (Postmes, Spears \& Lea 1998: 695) and shows that these links may be rather subtle (Haines et al. 2012). Some researchers postulate equalisation phenomena resulting from the lack of social context cues (e.g., Dubrovsky, Kiesler \& Sethna 1991; Kiesler \& Sproull 1992; Rhea et al. 2007), others attest de-individuation and, resulting from that, a decreased adherence to social norms and an increase in the expression of minority views (cf. Walther, Anderson \& Park 1994; Haines et al. 2012). The variance in effects, Postmes, Spears and Lea (1998: 695) argue, results from the fact that in analysing CMD, situational and local norms have been largely neglected in favour of more general social norms. In other words, the impact of the different communities of users (and their definitions of 'antinormative behaviour') has not been considered appropriately. Postmes, Spears and Lea (1998, 2000) point out that anonymity can cause an increased conformity to specific group norms, which might contradict general norms and promote stereotypes, ingroup favouritism and even outgroup hostility.

The two contrasting views on the effects of anonymity in CMC can be related to the two currently prevailing paradigms in politeness research: Second-order approaches, which define politeness based on the categories of theoretical models of politeness, and first-order approaches, which focus on the perception and coconstruction of certain types of behaviour as (im)polite by the participants of an interaction themselves, embedded in their own norms of interaction (for a more detailed discussion see Watts 2003, and Watts, Ide, \& Ehlich 2005). As both perspectives 
contribute to a more comprehensive understanding of (im)politeness phenomena, we have opted for a combination of first- and second-order approaches in this study.

The paper begins with a brief description of our data (section 2) followed by an extension of Kienpointner's (1997) system of intergroup rudeness, which is embedded in the context of second- and first-order perspectives on rudeness (sections 3.1 and 3.2). The first step of the actual analysis focuses on second-order tokens of intergroup rudeness. After a brief methodological discussion regarding the identification of such tokens in the two threads (section 3.3), section 3.4 outlines their actual usage in the two fora. The next major part takes a first-order perspective and focusses on metapragmatic utterances negotiating communicative norms in intergroup contexts (section 4). It starts with methodological considerations regarding the classification of such utterances (section 4.1), elaborates on major realisations of metapragmatic comments in both threads, and contrasts their usage (sections 4.2. and 4.3). Section 5 synthesises the findings from the first- and second-order perspectives, relating the distribution of second-order tokens of intergroup rudeness and evidence of their metapragmatic negotiation across the two threads.

\section{Data}

This study is part of a large-scale comparison of English and German forum discussions. The two sample threads cover the same topic and were chosen from a corpus of 40,000 postings for reasons of comparability: The English thread, drawn from the BBC's message board Have Your Say (HYS), contains 880 postings, and the German one, from Spiegel Online (SPON), consists of 754 postings. These discussion fora are embedded in mass media frames, attracting large numbers of users, and can be defined as public spaces (cf. Eysenbach \& Till 2001: 1104). The data were electronically retrieved and anonymised in line with common ethical principles. The two discussion threads were then imported into MAXQDA for the tagging of pragmatic and qualitative discourse-related categories, and the qualitative and quantitative analysis of the data. Each researcher tagged the corpus individually, then both discussed borderline cases and assigned categories jointly. To ensure comparability, the two threads deal with the same topic: The Pope's 2008 visit to the US. In HYS, the topic question is "Should the US give the Pope such a presidential welcome?" In SPON, participants were asked "Der Papst in den USA - Retter in der Not?" ('The Pope in the US - the saviour?'). The controversial nature of the topic ensured that the two threads proved rich in tokens of intergroup rudeness and related metapragmatic comments.

\section{Intergroup rudeness}

\subsection{Expanding Kienpointner's (1997) system}

In this study, we view intergroup rudeness as a special case of rudeness directed at groups and the group affiliation of individuals. Therefore, we see group membership as an essential part of an individual's social identity (cf. Tajfel 1978). We are particularly interested in group-face sensitivities, which are linked up with the sensitivities of a group one belongs to or identifies with, and which are closely intertwined with 
individuals' face concerns (Spencer-Oatey 2005; Bousfield 2008). In fact, our data bear evidence of gradual transformation processes from interpersonal encounters to intergroup encounters. As the threads unfold, participants more or less explicitly reveal their own group memberships and assign in- or outgroup status to their co-participants. The specific medium factors of Internet discussion fora (cf. Herring 2007) largely restrict participants to textual means of group construction, including rudeness tokens, metapragmatic comments and explicit self-affiliation via the propositional content of the postings (e.g., I'm a Christian (HYS\#409)).

Thus, intergroup rudeness is an important interactive practice in the creation and maintenance of the boundaries that define groups. As an evaluative attitude with a focus on the perceptive side of rudeness, it "is sustained by expectations, desires and/or beliefs about social organisation, including, in particular, how one person's or group's identities are mediated by others in interaction" (Culpeper 2010: 3233). This mediation is intertwined with the co-construction of face. On the one hand, many encounters within the threads oscillate between interpersonal and intergroup levels. Quite commonly, an insult to a thread-internal addressee is 'offensive' or 'impolite' to the members of his/her group in the thread. In turn, an insult directed at the entire group will be perceived as offensive by an individual member. On the other hand, rudeness tokens directed at thread-external targets can also have an offensive effect on members of thread-internal groups affiliated with that target.

According to Kienpointner (1997: 276ff.), who focusses on the productive side of rudeness, intergroup rudeness can be characterised as a non-cooperative, motivated form of rudeness which occurs in two major hierarchical constellations. Type I comprises rudeness strategies used by majority groups as a means to degrade members of certain outgroups; Type II refers to the use of rudeness by minority groups as a means of social self-defence and political criticism (Table 1). However, in view of natural CMD, Kienpointner's classification of intergroup rudeness needs to be refined and expanded.

In order to cover the different types found in our data, we postulate two additional categories of intergroup rudeness (Types III and IV, see Table 1), which can be found not only in the two discussion threads studied here but appear to be characteristic of many (political) forum discussions.

Table 1: Types of intergroup rudeness in Internet discussion fora

\begin{tabular}{|l|l|}
\hline Type I & Type II \\
Majority $\rightarrow$ Minority & Minority $\rightarrow$ Majority (outside forum) \\
\hline Type III $\rightarrow$ Outgroup (within forum) & Type IV \\
Ingroup $\rightarrow$ Ingroup $\rightarrow$ Outgroup (outside forum) \\
\hline
\end{tabular}

Types III and IV cover the construction of non-hierarchical in- and outgroups. Here, social identity is established and evaluated through the comparison of the ingroup with relevant outgroups. Typically, the various camps consider themselves as 'ingroups' and see the others as 'outgroups'. Thus, the discussions display differences in self- and otherperception and are characterised by permanent shifts of deictic perspectives.

Whereas Type III covers group construction within the forum as in example (1), Type IV refers to cases in which participants construct certain outgroups outside the forum as hierarchically equal (example (2)). The construction of the respective in- and outgroups via rudeness tokens often displays an ingroup bias, in that outgroups are latently represented as inferior. 
(1) I see that the mental midgets are out in force once again within this thread. (HYS\#575)

(2) I would have thought that the US is an ideal place for the Pope. It's full of religious zealots and wierdos so he should feel at home. (HYS\#831)

\subsection{Intergroup rudeness from a first- and second-order perspective}

Adopting a discursive approach in which politeness norms are seen and analysed as constructed in on-going discourse, we must acknowledge that linguistic behaviour which might be perceived as rude by outsiders of certain communities could be considered by the participants themselves as perfectly appropriate, 'politic behaviour' in Watts' sense (2003: 161). However, like Culpeper (2011: 31ff.), we assume that there is also a set of shared conventions which allows for the intuitive (out-of-context) judgements people make about certain expressions. These often coincide with categories of impoliteness established in theoretical models.

In accordance with Watts (2005) and Culpeper (2011), we consider 'politic behaviour' and '(im)politeness'/'rudeness' as points on a scale rather than categories with clear-cut boundaries. This begs the question of how 'politic behaviour' and 'rudeness' can be verified in the specific conversational context of an anonymous public online discussion, where participants do not always provide systematic feedback sanctioning an interpretation of 'rudeness' interactions. ${ }^{2}$ Certainly, lack of feedback does not necessarily mean that participants have not interpreted an utterance as 'rude' (Kleinke 2007). Additionally, due to the polylogal and public character of forum interaction, participation roles are far more complex and less clear than in natural face-to-face interaction. A posting may be addressed to a single co-participant, but it is, at the same time, received by the whole group and an unknown number of lurkers (including the researchers). Especially in the context of intergroup rudeness, it is not always clear whether the addressee is an individual participant or the 'whole group'. A message can be considered rude provided "a recipient or a third party interpret it as such" (Maricic 2005: 61), meaning the individual perception of rudeness by the intended addressee loses importance in the public space of forum discussions. Judgments of rudeness as well as loss of face are no longer restricted to the immediately active, individual discourse participants. Finally, just as in face-to-face interaction, individual participants will have different understandings of the norms of interaction, regardless of conventionalised rudeness tokens (Culpeper 2011: 14f.). ${ }^{3}$

Our assessments in this study are guided by a careful analysis of the co-text (including the unfolding discussion in its entirety as well as the micro-level of a single posting) and thread-internal metapragmatic comments (cf. Culpeper's approach (2011)). However, in order to gain a better understanding of the internal norms of politic behaviour in the two discussions, a thorough analysis of how conventional impoliteness formulae are used throughout the thread was also essential. We thus opted for a twolevel analysis placing the study at the interface of first- and second-order approaches.

\footnotetext{
${ }^{2}$ Emoticons supporting an interpretation are rare and mainly confined to instances of belittling in the two threads investigated. Where they occur, they generally serve an evaluative function, especially in the German thread in instances of belittling (cf. Dresner \& Herring 2010).

${ }^{3}$ In the present study, the consensus of the two authors was high, although inter-rater agreement was not statistically measured.
} 
In contrast to Watts (2003), we do not see such a clear-cut boundary between strategies outlined in theoretical models of politeness (second-order perspective) and laypersons' perceptions of token structures realised in specific contexts as rude (firstorder perspective). Drawing on Culpeper (2010, 2011), we assume that a possible bridge between the two perspectives is our conventionalised knowledge about the potentially rude impact of such token constructions outside specific contexts. This knowledge is part of our frame- and scheme-based knowledge (Culpeper 2010, 2011) and deeply entrenched in our cultural models about cooperative interaction (Maricic 2005; Kleinke 2010). It is transferred, among other means, via 'metadiscourse', which, as an "[i]ndirect experience" of impoliteness, "plays a role in the group dynamic that gives rise to a behaviour being evaluated as impolite in the first place" (Culpeper 2010: 3238f.).

Although "most forms of social interaction have become institutionalised and [...] the appropriate discursive practices are known to us beforehand" (Watts 2003: 20), conventionalised rudeness ${ }_{2}$ tokens are subject to negotiation as actually 'rude' in specific contexts, and need to be verified by the researcher. Yet in order to see precisely how a particular community handles and interprets these tokens, we need to know where and how they are used.

The first level of the analysis therefore identifies the most frequent types of second-order tokens of intergroup rudeness (intergroup rudeness 2 for short) and their distribution in the English and the German threads. We believe that without taking on such a systematic second-order perspective, preferably even prior to a first-order perspective, it is impossible to verify how exactly "language shapes (and constructs) the situation", and how "the situation shapes language" (Bousfield 2008: 170), not only for a single isolated interaction but also to reveal more generally valid patterns.

The second level of the analysis takes on a first-order perspective, investigating the metapragmatic comments in the corpus. We focus on the questions of how metapragmatic comments are used for the discursive struggle over intergroup rudeness, and how they display expectations regarding unmarked or politic behaviour in online discussion fora dealing with highly controversial topics. As we will discuss below, our analysis of metapragmatic comments suggests that what is 'expectable' and 'common' (judging by the mere frequency of rudeness 2 tokens) and what thus helps "establish the type of interaction" and "make it recognisable" as an online discussion (Watts 2003: 19; Locher \& Bousfield 2008: 8) is not necessarily seen as 'appropriate' and 'politic' by all participants.

Summarising our preliminary considerations, we assume that the participants in the two discussions have both a (quasi) second-order understanding of rudeness, resulting from their cultural and frame knowledge in the widest sense, and a first-order understanding, arising from their knowledge of the discursive, contextual level of situated discourse, both of which feed into their use and negotiation of rudeness token structures. The following section outlines the types of second-order tokens of rudeness found in the two threads and briefly discusses how the categories were applied in the actual analysis. 


\subsection{Methodology: Second-order tokens of intergroup rudeness in HYS and SPON}

We decided to base our own classification on "conventionalised impoliteness formulae" (Culpeper 2010, 2011), as we consider these to be the linguistic link between our two levels of description. Although used as the descriptive tool in a linguistic model (thus serving a second-order perspective), they are retrieved from metadiscourse about impoliteness in private, "that is, ingroup contexts" in a speech community (Culpeper 2010: 3240f.). Thus, they incorporate a first-order perspective, presenting an insight into super-individual knowledge of the speakers about "what counts as rude". Drawing on Culpeper's categories and also on the strategies outlined in earlier models (e.g., Culpeper 1996; Kienpointner 1997; Bousfield 2008), an inventory for our special type of discourse was developed. Even though these classifications were designed against the background of British culture, we had no difficulty in recognising the same categories in our German material. The categories are exemplified and arranged in descending order according to their frequency in the two threads in (i) - (iv).

\section{(i) Pointed criticism}

This category comprises instances of criticism against specific types of conduct, actions, statements made by a target, etc., which are realised by "expressions of disapproval and statements of fault, weakness or disadvantage", and produce or perceive "a display of low values for some target" (Culpeper 2010: 3241).

(3) I find it absolutely sickening ${ }^{4}$ how excessive and extravagant the Pope's welcome has been by the US President, ... (HYS\#385)

(4) Lohnt sich eine Entgegnung überhaupt bei so viel Hass und Unkenntnis? (SPON\#98) ('Is it even worth responding to so much hatred and ignorance?')

(ii) Insult

Token structures of this category include "derogatory statements and implications" directed at the personal traits of some target, displaying "low values for some target", "derogatory statements about people of another race, religion or lifestyle" (Culpeper 2010: 3241), as well as participants' use of inappropriate identity markers with an insulting impact (see also Bousfield 2008: 95; Kienpointner 2008: 256).

(5) ... But I didn't expect anything less from our fascist, idiotic twit of a president. (HYS\#405)

(6) Eigentlich ist jedes Wort über so einen Klerofaschisten überflüssig... (SPON\#9)

('Really, every word about a clero-fascist like him is one too much...')

(iii) Belittling

The third category comprises ridiculing, demeaning behaviours (Culpeper 2010: 3240) and the use of inappropriate identity markers with a clearly disparaging flavour (Kienpointner 1997: 276). In our data, belittling contributes to rhetorical effect and entertainment - highly valued goods in forum discussions, where interactants seek to attract attention.

\footnotetext{
${ }^{4}$ Bold type is authors' emphasis in all examples to follow.
} 
(7) Great suffering for the church???? What about great suffering for the victims. So one elderly German in a badly fitting white frock says sorry in English and that makes everything OK does it? (HYS\#4)

(8) ... Da stinkt der Alte im Weihnachtsmannkostüm aber ab! ;-) (SPON\#72) ('Tough luck for the old guy in the Santa costume! ;-)')

(iv) Patronising behaviour

We classified token structures as patronising behaviour in instances where the poster produces or perceives "a display of power that infringes an understood power hierarchy" (Culpeper 2010: 3240), i.e., when posters could not really encroach upon their targets, but behaved as if they could. In the context of the two threads studied here this may include telling other posters (with an equal standing in the power hierarchy of the forum) or 'majority'-targets how to behave and what to do.

... Oh do stop playing the victim card. (HYS\#514)

(10) ... Das Geld für diesen Funtrip hat die RKK gefälligst anderweitig zu investieren! (SPON\#79)

('Will the Roman Catholic Church kindly invest the money for this fun trip in another way!')

Naturally, these categories, which are all related to the domain of human emotional experience, are not to be interpreted as mutually exclusive (see also Bousfield 2008: 99f.). Category boundaries are rather fuzzy and the links between them appear reminiscent of a 'family resemblance'. Therefore we allowed for double-labelling in cases such as (10), which is interpretable as an instance of patronising and which, due to its strong imperative force highlighted by the German particle gefälligst (with its more forceful negative connotation than the English adverb kindly when used sarcastically), may also have an implicit downgrading and thus insulting impact.

The specific linguistic output strategies (e.g., inappropriate identity markers) may occur across categories. See, for example, the use of the inappropriate identity marker in (8), where der Alte im Weihnachtsmannkostüm ridicules the Pope and has a predominantly belittling effect, as compared to (11), where the ridiculing component is missing and the unsuitable identity marker Ratzinger has an insulting impact within an instance of pointed criticism. In cases such as (8) we decided for single-labelling. In contrast, rudeness $s_{2}$ tokens such as in (11) were seen as multiple realisations and doubletagged for the predominant interpretation of the inappropriate identity marker and possible additional categories (e.g., pointed criticism in this case). Realisations of several different types of rudeness ${ }_{2}$ in one posting as in (12) (with rudeness types in square brackets) and virtual cascades of realisations of the same type (here: 'pointed criticism'), as in (13), were tagged for each single instance and, due to their intensifying effect, additionally coded as 'multiple realisations' (see Figure 1).

(11) ... By forbidding contraception (a purely invented dogma), Ratzinger [Insult] is responsible for both over-population and AIDS in the third world [Pointed Criticism]. (HYS\#159)

(12) It doesnt bother me what the USA does, as long as we don't ever give the Pope a similar welcome here in Britain. That man had the gall to say athiests were responsible for 
most of the worlds wars and disasters. [Pointed criticism] How does that work Ratzinger? [Insult] Wasn't Hitler a Catholic? [Insult] Being a former member of the Hitler youth, I am sure Ratzinger must know! [Insult] As far as I am concerned, Catholicism is responsible for maliciously keeping half of the worlds population in poverty. ... [Pointed criticism] [Multiple realisations] (HYS\#159)

(13) Don't pres. Bush and the Pope have enough common interests not to like each other? [Insult] Don't they both maintain enough skeletons in their closets not to fear each other? Don't they both carry enough negative political baggage not to need each other? [Insult] Don't they both like the fringes and pomp of their positions equally well? [Insult] Don't they both cater to the business of religion in rather usury fashion? [Insult] Aren't they both on the way out... for the good of the world perhaps? [Insult] [Multiple realisations] (HYS\#554)

(14) ... Of all the people in the world to choose to bestow a special honour on I would have thought this Pope was well down the list [Insult]. (HYS\#710)

Irony and humorously coloured mitigating strategies as in (8) or (14) are used occasionally, but not in sufficient quantities to change the tone of the entire discussions from 'rather harsh' to 'friendly'. Nevertheless, they are part and parcel of the specific nature of online political discussions, where rather subtle, rhetorically sophisticated 'offrecord'-criticism often takes precedence over more direct 'on-record' strategies and is likely to enhance the prestige of a participant. Therefore, we also included rudeness 2 tokens where an interpretation as rude is triggered by an implicature rather than the surface realisation per se (cf. Culpeper 2010). See (14), for example, which was tagged as an insult.

\subsection{Results: Rudeness ${ }_{2}$ tokens as manifestations of intergroup rudeness in HYS and SPON}

Intergroup rudeness ${ }_{2}$ of Type II, III and IV (cf. Table 1 above) figured prominently in our data, which provided plenty of instances in all four types of rudeness 2 tokens (a total of 1420 tagged instances in 1634 postings). Their occurrence coloured the overall atmosphere in both fora as rather conflictive. Since each occurrence of each rudeness type was tagged, one posting could include more than one token of a given type. Figure 1 summarises the percentage of postings containing the various types of intergroup rudeness 2 . It shows that only $32 \%$ of the postings in HYS and $39 \%$ of the postings in SPON are 'unmarked' for rudeness 2 , i.e., they contain no rudeness ${ }_{2}$ tokens (cf. column 8). All other postings include one or more rudeness ${ }_{2}$ tokens, and these were neither confined to only a few users nor to only a few segments of the discussions. Although the descending distribution of the four categories is somewhat similar for both threads, there are considerably more rudeness taggings within the posts that contain rudeness in HYS $(n=869)$ than in SPON $(n=551)$. 


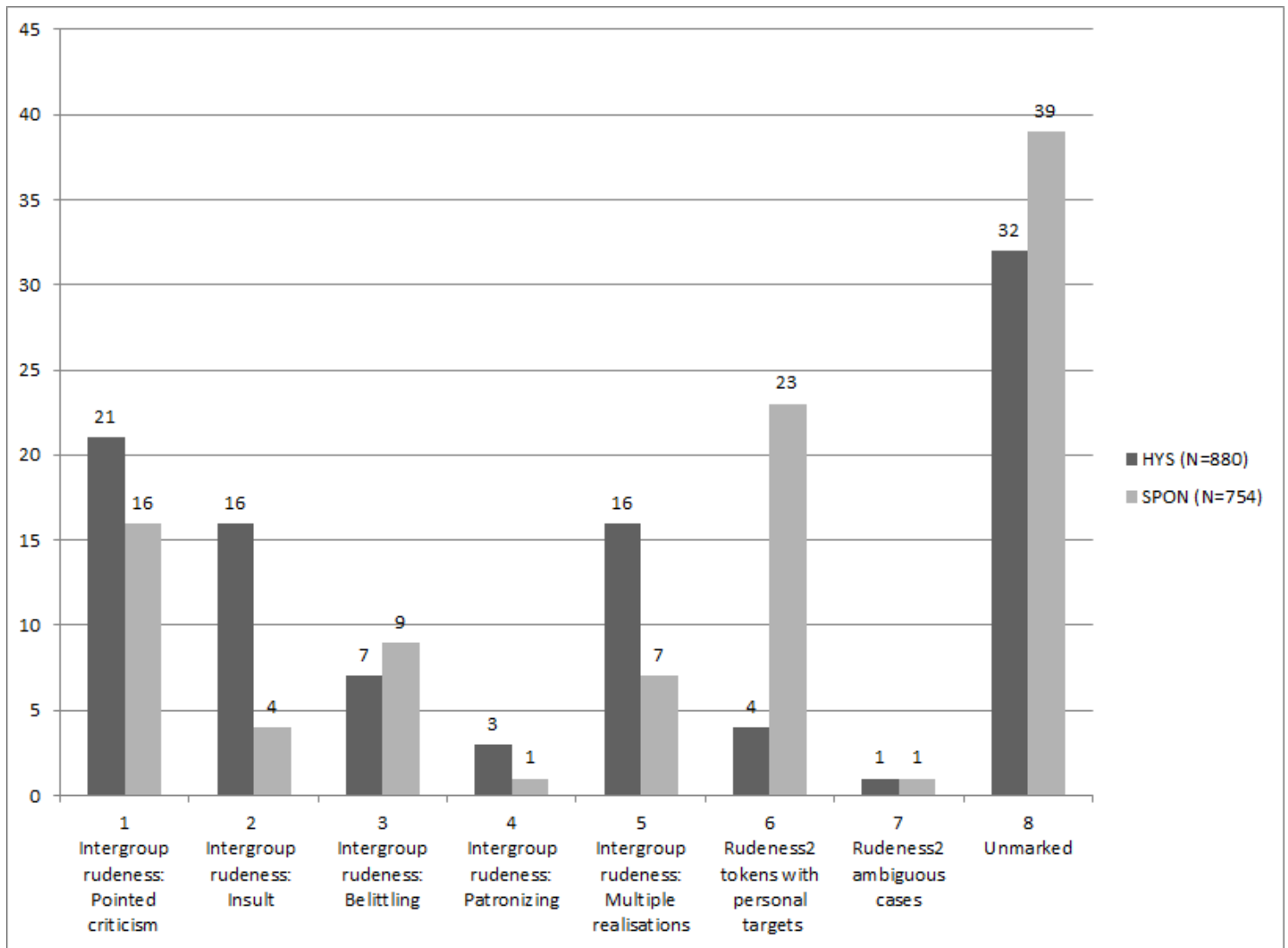

Figure 1: Percentage of postings containing rudeness 2 tokens in HYS and SPON

Columns 1-4 and 6-7 show postings featuring only one type of rudeness 2 per posting, which constitute the majority in our threads (contrary to Bousfield's data, 2008: 146). However, column 5 shows that there are also many postings with multiple realisations of different types of rudeness 2 . Interestingly, such multiple realisations occurred far more frequently in HYS (in about $16 \%$ of all postings vs. about $7 \%$ of all postings in SPON), despite the fact that on average the postings are shorter (HYS: 128 words vs. SPON: 196 words). As to be expected in the 'discussion' frame, the most prominent category in both threads is 'pointed criticism,' occurring in $21 \%$ of all postings in HYS (which also accounts for about 21\% of all 869 rudeness 2 -taggings in HYS) and in 16\% of all postings in SPON (which accounts for about 22\% of all 551 tagged cases in SPON).

Despite these similarities, HYS displays a much higher frequency of intergroup rudeness $s_{2}$ tokens, frequently used in multiple realisations within a single posting, and a much higher frequency of insulting postings, which occur in four times as many postings in HYS as in SPON. These features suggest an overall higher degree of intergroup hostility in the English-speaking thread. However, this general impression warrants some refinement linked to the actual targets of rudeness $s_{2}$ tokens, which we turn to now.

Users of SPON direct their rudeness 2 tokens almost four times as often as users of HYS against personal targets or targets for which a personal interpretation cannot be excluded (Figure 1, columns 6-7), which is quite in tune with our metapragmatic findings (see section 4.3.). Table 2 shows that the two threads also vary in their rudeness $s_{2}$ practices with regard to the different outgroups as targets. The table builds on 
our refined system of types of intergroup rudeness (see Table 1). It summarises major group constellations documented in HYS and SPON for a total of 1189 intergroup rudeness $s_{2}$ tokens directed at majority group targets (Type II), outgroup targets inside the discussion forum (Type III), or outgroup targets outside the forum (Type IV).The remaining rudeness ${ }_{2}$ tokens are directed at individual personal targets (including 13 ambiguous cases of a total of 46 in HYS and only 6 ambiguous cases of a total of 185 in SPON) in the forum.

Table 2: Group constellations in intergroup rudeness ${ }_{2}$ of Types II , III and IV

\begin{tabular}{|c|c|c|}
\hline \multicolumn{3}{|c|}{ Rudeness $_{2}$ tokens and their targets in \% } \\
\hline \multicolumn{3}{|c|}{$\mathrm{N}$ total $=1189$} \\
\hline $\begin{array}{c}\text { HYS } \\
\mathrm{N}_{\text {total }}=823 \text {, i.e., } 1 \text { instance per } 1.1 \\
\text { postings }\end{array}$ & \multicolumn{2}{|c|}{$\begin{array}{c}\text { SPON } \\
\mathrm{N}_{\text {total }}=\text { 366, i.e., } 1 \text { instance per } 2.1 \text { postings }\end{array}$} \\
\hline \multicolumn{3}{|c|}{$\begin{array}{c}\text { Type II } \\
\text { Minority } \rightarrow \text { Majority (outside forum) } \\
\mathrm{N}_{\text {TypeII }}=924\end{array}$} \\
\hline $\mathrm{N}_{\text {TypeII }}=680 \quad \mathrm{~N}_{\mathrm{T}}$ & \multicolumn{2}{|l|}{$\mathrm{N}_{\text {TypeII }}=244$} \\
\hline Participants vs. Pope & Participants vs. Catholic Church & 37.4 \\
\hline Participants vs. Catholic Church & Participants vs. Pope & 19.4 \\
\hline Participants vs. Bush & Participants vs. Bush & 4.6 \\
\hline Participants vs. HYS & Participants vs. Bush and Pope & 3.3 \\
\hline Participants vs. Bush and Pope & Participants vs. SPON & 1.6 \\
\hline Participants vs. US-Government & & \\
\hline Participants vs. Gordon Brown & & \\
\hline \multicolumn{3}{|c|}{$\begin{array}{c}\text { Type III } \\
\text { Ingroup } \rightarrow \text { Outgroup (inside forum) } \\
\mathrm{N}_{\text {TypeIII }}=212\end{array}$} \\
\hline \multicolumn{3}{|c|}{ 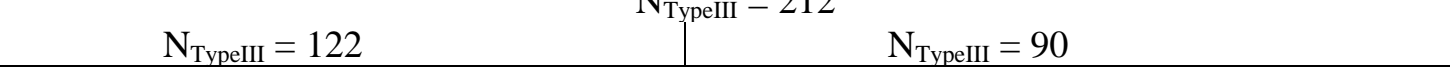 } \\
\hline $\begin{array}{l}\text { Pro-church vs. contra-church } \\
\text { camps }\end{array}$ & $\begin{array}{l}\text { Pro-church vs. contra-church } \\
\text { camps }\end{array}$ & 23.2 \\
\hline $\begin{array}{l}\text { Pro-UK/USA vs. contra- } \\
\text { UK/USA }\end{array}$ & Pro-UK/USA vs. contra-UK/USA & 1.4 \\
\hline \multicolumn{3}{|c|}{$\begin{array}{c}\text { Type IV } \\
\text { Ingroup } \rightarrow \text { Outgroup (outside forum) }\end{array}$} \\
\hline $\mathrm{N}_{\text {TypeIV }}=21$ & $\mathrm{~N}_{\text {TypeIV }}=32$ & \\
\hline Participants vs. Muslims & Participants vs. US Americans & 6.6 \\
\hline Participants vs. US Americans & Participants vs. Muslims & 2.5 \\
\hline Total (\%) & Total (\%) & $\overline{100.0}$ \\
\hline
\end{tabular}

Whereas intergroup rudeness of Kienpointner's Type I did not occur in our corpus, Table 2 shows that there were vast quantities of Type II examples and a considerable number of Type III tokens exchanged between the pro-church vs. contra-church and pro UK/USA vs. contra UK/USA camps. Type II includes rudeness 2 tokens with a venting function, which are typically directed against major institutions representing the political and social 'majority'. In Table 2, they are arranged according to the frequency of their targets in the threads. The ratios of intergroup rudeness 2 tokens per postings illustrate that the English thread produces more than twice as many in total and clearly outscores the German thread in virtually every category, except Type III. In HYS only 
about $15 \%$ of all intergroup rudeness 2 tokens are directed at outgroups present in the forum (i.e., Type III targets, see Table 2). The score is higher in SPON, where about $25 \%$ of these token structures are directed at outgroup members actually participating in the discussion, enhancing the imposition.

Accounting for different targets of intergroup rudeness also refines the ratio of tokens in the category 'belittling' shown in Figure 1: On the surface of postings containing token realisations, both threads achieve roughly equal percentages. As Table 2 shows, in both threads, tokens also far more frequently target majority groups not 'immediately present' in the (virtual) discussion, who cannot defend themselves. However, not only is the overall ratio of Type III rudeness higher in the German thread, Type III targets (mainly members of the pro-/contra-church outgroups) also receive a considerable number of all belittling tokens (SPON: 18\% of the total 115 belittling tokens vs. HYS: $0.5 \%$ of the total 122 belittling tokens). In the English thread, almost all instances of belittling are directed at Type II targets.

Thus, in our corpus, especially in the German thread, rudeness 2 tokens are not confined to socially distant targets but are also used systematically against hierarchically equal co-participants. Given the multitude of rudeness 2 tokens, it does not come as a surprise that they also feature frequently in metapragmatic comments, as the following sections show.

\section{Metapragmatic utterances in online discussion fora}

Due to their asynchronicity, Internet discussions allow participants (at least potentially) to take their time in the production and interpretation of postings and to "reflect and comment on their own and their fellow participants' contributions" (Tanskanen 2007: 89). As the tokens in our corpus prove, metacommunication is an important argumentative resource in the negotiation of norms and expectations in our fora (cf. Schütte 2000). With the examination of metapragmatic elements, we enter the second level of analysis, adopting a first-order perspective.

Here, we are not so much concerned with explicit norms as codified in netiquette guides or FAQ sections, although the latter are available for both HYS and SPON, and provide some general guidelines regarding the use of technology and language. Rather, we are interested in the implicit norms that are negotiated in the interactions themselves. As Burnett and Bonnici (2003: 349) state, "implicit norms that emerge through such [meta]discussions sometimes contradict, expand, or modify the explicit norms articulated in the groups' FAQs" (see also Korenmatt \& Wyatt 1996; Graham 2007).

What is particularly important in this study is how metapragmatic elements are used in negotiating ingroup and outgroup status within the threads. Thus, we concentrate on metapragmatic utterances in the narrow sense (cf. Caffi 1998: 581), i.e. those elements that provide an assessment regarding the appropriateness of participants' communicative behaviour and/or feedback on the ongoing discussions as such, and even more particularly, on "impoliteness metadiscourse [...] driven by the need to demonstrate one's own orientation to a group and the norms by which it is constituted" (Culpeper 2010: 3239). 


\subsection{Methodology: Classification of metapragmatic utterances}

Based on the taxonomies suggested by Hübler and Bublitz (2007), Tanskanen (2007), and Weder (2008), we developed a classification scheme for metapragmatic utterances, geared to our material and research question. Every metapragmatic utterance in the corpus was tagged with regard to four major variables: TARGET, EVALUATIVE/NORMRELATED FUNCTION, TONE, and FEATURE OF THE POSTING/THREAD REFERRED TO. Table 3 provides an overview of the four variables and their respective values, which (for the sake of brevity) are mainly illustrated with examples from HYS.

The classification applied here faces the same challenges as most pragmatic classifications (including that of rudeness 2 tokens): The values of a certain variable are not always mutually exclusive, and multiple tagging within a category is the rule rather than the exception. Yet, there is not only the phenomenon of multiple values, as typically illustrated by the variables FUNCTION and FEATURE REFERRED TO. Many of the values outlined here are also characterised by their fuzzy boundaries. For example, the variable TONE, which "refers to the manner or spirit in which discursive acts are performed" (Herring 2007: 21) comprises the values 'convivial', 'neutral/unmarked', and 'non-convivial' as mere anchoring points on a scale of aggressiveness often supported by further values of the same variable.

Table 3: Classification of metapragmatic utterances

\begin{tabular}{|c|c|c|}
\hline VARIABLE & VALUE & EXAMPLES \\
\hline \multirow{9}{*}{ 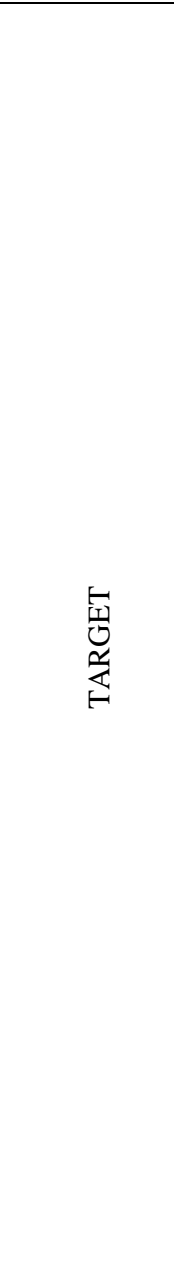 } & self-directed & $\begin{array}{l}\text { I hope you dont think this this is a hateful attack on } \\
\text { the people of America or on the pope but this is the } \\
\text { truth (HYS\#409) }\end{array}$ \\
\hline & \multicolumn{2}{|l|}{ other-directed: } \\
\hline & personal & $\begin{array}{l}\text { If the Pope is an international genocidal criminal, I'd } \\
\text { be interested to know what scorn you reserve for Idi } \\
\text { Amin, Gadaffi, Bin Laden, Pol Pot, Ansar Al Islam } \\
\text { and the IRA. (HYS\#291) }\end{array}$ \\
\hline & ingroup & $\begin{array}{l}\text { Dies ist den Foristen zu verdanken, die eine klare } \\
\text { sachliche (Glaubens-)Position beziehen ohne die } \\
\text { Meinung der Anderen niederzumachen. Danke } \\
\text { \{\{participant_17\}\}, \{\{participant_6\}\} (SPON\#752) } \\
\text { (We can thank the forum participants for taking a } \\
\text { clear and objective position (of belief) without } \\
\text { trampling on the opinions of others. Thank you } \\
\{\{\text { participant_17\}\}, }\{\text { \{participant_6\}\}) }\end{array}$ \\
\hline & outgroup & $\begin{array}{l}\text { I would just say to the HYS crowd, develop some } \\
\text { manners and show some respect to a man of the } \\
\text { cloth. (HYS\#703) }\end{array}$ \\
\hline & unspecified group & $\begin{array}{l}\text { But the cruel and rabid tone of many comments on } \\
\text { this HYS topic, are totally off-base. (HYS\#677) }\end{array}$ \\
\hline & fuzzy: personal/group & $\begin{array}{l}\text { You can believe what ever you want but do not } \\
\text { indoctriante me with your believes. As an athisist I } \\
\text { can reassure you that } \mathrm{i} \text { am } 1000 \mathrm{X} \text { more tolerant than } \\
\text { an religiouse fanatic. (HYS\#392) }\end{array}$ \\
\hline & $\begin{array}{l}\text { whole thread/all thread } \\
\text { members }\end{array}$ & $\begin{array}{l}\text { Can someone tell me why Catholic bashing is so } \\
\text { prevalent? (HYS\#522) }\end{array}$ \\
\hline & institution & $\begin{array}{l}\text { The BBC is promoting Rerligious hatred against the } \\
\text { Roman Catholic Church (HYS\#566) }\end{array}$ \\
\hline
\end{tabular}




\begin{tabular}{|c|c|c|}
\hline \multirow{6}{*}{ 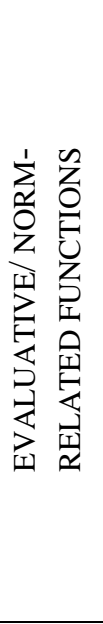 } & instructive & $\begin{array}{l}\text {... I will conclude by saying that if u do not believe, } \\
\text { shut up and do not paint others black because they } \\
\text { do not fit in your personal picture of how things } \\
\text { should be. (HYS\#325) }\end{array}$ \\
\hline & appellative & $\begin{array}{l}\text { Come on show some compassion and respect } \\
\text { (HYS\#204) }\end{array}$ \\
\hline & supportive/affiliative & Absolutely spot on (HYS\#729) \\
\hline & $\begin{array}{l}\text { conflictual/provocative } \\
\text { (face-threatening) }\end{array}$ & What drivel. What sectarian drivel (HYS\#565) \\
\hline & expressive & $\begin{array}{l}\text { I've been reading through some of these comments } \\
\text { and I'm shocked at the inaccuracies and sheer } \\
\text { bigotry... (HYS\#545) }\end{array}$ \\
\hline & defensive & $\begin{array}{l}\text { No, not Catholic beashing but reality checking. } \\
\text { (HYS\#139) }\end{array}$ \\
\hline \multirow{6}{*}{$\sum_{0}^{1}$} & neutral/unmarked & He treats us with respect, so should we (HYS\#332) \\
\hline & convivial & Absolutely spot on (HYS\#729) \\
\hline & non-convivial & $\begin{array}{l}\text { The comments on this debate are disgusting } \\
\text { (HYS\#401) }\end{array}$ \\
\hline & humorous & $\begin{array}{l}\text { Hello and welcome to HYS, you're obviously new } \\
\text { here... (HYS\#111) }\end{array}$ \\
\hline & ironic/sarcastic & $\begin{array}{l}\text { Wow! I thought the typical BBC crowd only } \\
\text { reserved such hate for Jews and GW Bush } \\
\text { (HYS\#80) }\end{array}$ \\
\hline & patronising & $\begin{array}{l}\text { Some of you need to get your own houses in order } \\
\text { and show a little RESPECT (HYS\#503) }\end{array}$ \\
\hline \multirow{4}{*}{ 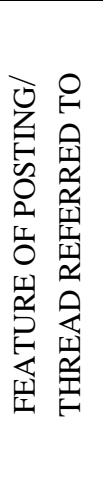 } & existence & $\begin{array}{l}\text { I am suprised that the moderator has left through } \\
\text { some of the comments... (HYS\#24) }\end{array}$ \\
\hline & style & $\begin{array}{l}\text { Is this a rosary of vitriolic comments, the nastiest } \\
\text { being repeated the most often? (HYS\#438) }\end{array}$ \\
\hline & propositional content & $\begin{array}{l}\text { As an atheist and free thinker I have to say I find } \\
\text { some (well, many) of the comments here pathetic... } \\
\text { (HYS\#503) }\end{array}$ \\
\hline & spelling/grammar & $\begin{array}{l}\text { Wenn Sie den Titel noch nicht mal schreiben } \\
\text { können, glaube ich das gern. (SPON\#5) } \\
\text { (If you can't even spell the title correctly, I can well } \\
\text { believe that') }\end{array}$ \\
\hline
\end{tabular}

With respect to the TARGET, we agreed to set up an extra category for fuzzy cases of personal/group reference, which proves particularly interesting with respect to our research focus. For all other overlaps and fuzzy cases of values, we allowed for multiple tagging. For instance, (15) was tagged as: TARGETed at the outgroup (nonCatholics), instructive and conflictual/provocative in FUNCTION, non-convivial and patronising in TONE, and referring to the FEATURES of propositional content and the style of outgroup members' postings.

(15) Why are so many of you trying to criticise the Pope pewrsonally and the rekligion he rep[resents? If you don't like our religion then please have the basic decency and manners to keep your opinions to yourselves. We don't make childish, inaccurate \& sweeping statements about you (tempting though it is, sometimers). (HYS\#31) 


\subsection{Results: Overview of the metapragmatic utterances in HYS and SPON}

Table 4 summarises the characteristics of metapragmatic comments in our corpus. In total, 297 metapragmatic utterances were tagged (95 in HYS and 202 in SPON). As pointed out above, we allowed for multiple tagging within the four variables in order to represent the complexity of such comments as faithfully as possible. Thus, the number of values tagged exceeds the total number of metapragmatic utterances. The percentages provided in the table refer to the number of metapragmatic utterances tagged for a certain value in HYS, SPON and the whole corpus respectively.

Table 4: Metapragmatic utterances in HYS and SPON

\begin{tabular}{|c|c|c|c|c|c|c|}
\hline \multirow[t]{2}{*}{ VARIABLE } & \multirow[t]{2}{*}{ VALUE } & \multicolumn{2}{|l|}{$\begin{array}{l}\mathrm{HYS} \\
\mathrm{N}=95\end{array}$} & \multicolumn{2}{|l|}{$\begin{array}{l}\text { SPON } \\
\mathrm{N}=202\end{array}$} & \multirow{2}{*}{$\begin{array}{l}\text { TOTAL } \\
\mathrm{N}=297 \\
\%\end{array}$} \\
\hline & & Tags & $\%$ & Tags & $\%$ & \\
\hline \multirow{8}{*}{ 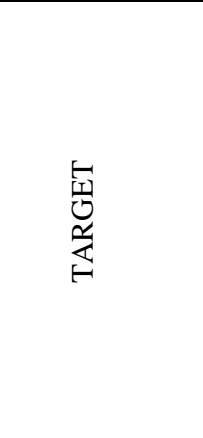 } & self-directed & 4 & 4.2 & 28 & 13.9 & 10.8 \\
\hline & personal & 12 & 12.6 & 89 & 44.1 & 34.0 \\
\hline & ingroup & 2 & 2.1 & 15 & 7.4 & 5.7 \\
\hline & outgroup & 37 & 38.9 & 39 & 19.3 & 25.6 \\
\hline & unspecified group & 14 & 14.7 & 7 & 3.5 & 7.1 \\
\hline & fuzzy: & 4 & 4.2 & 24 & 11.9 & 9.4 \\
\hline & person/group & 4 & 4.2 & 5 & 2.5 & 3.0 \\
\hline & $\begin{array}{l}\text { whole thread } \\
\text { institution }\end{array}$ & 25 & 26.3 & 5 & 2.5 & 10.1 \\
\hline \multirow{6}{*}{ 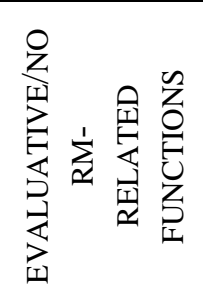 } & instructive & 6 & 6.3 & 3 & 1.5 & 3.0 \\
\hline & appellative & 9 & 9.5 & 4 & 2.0 & 1.7 \\
\hline & supportive/affiliative & 1 & 1.1 & 24 & 11.9 & 8.4 \\
\hline & conflictual/provoca- & 55 & 57.9 & 152 & 75.2 & 69.7 \\
\hline & expressive & 29 & 30.5 & 18 & 8.9 & 15.8 \\
\hline & defensive & 3 & 3.2 & 25 & 12.4 & 9.4 \\
\hline \multirow{6}{*}{$\sum_{0}^{1}$} & neutral/unmarked & 15 & 15.8 & 17 & 8.4 & 10.8 \\
\hline & convivial & 3 & 3.2 & 13 & 6.4 & 5.4 \\
\hline & non-convivial & 60 & 63.2 & 123 & 60.9 & 61.9 \\
\hline & humorous & - & - & 15 & 7.4 & 7.4 \\
\hline & ironic/sarcastic & 10 & 10.5 & 25 & 12.4 & 11.8 \\
\hline & patronising & 13 & 13.7 & 35 & 17.3 & 16.2 \\
\hline \multirow{4}{*}{ 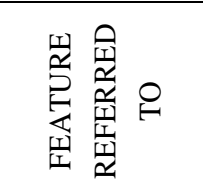 } & existence & 1 & 1.1 & 8 & 4.0 & 2.4 \\
\hline & style & 50 & 52.6 & 91 & 45.0 & 47.5 \\
\hline & propositional content & 86 & 90.5 & 164 & 81.2 & 84.2 \\
\hline & spelling/grammar & - & - & 22 & 10.9 & 10.9 \\
\hline
\end{tabular}

Table 4 shows that, regarding the TARGET, both threads show a clear dominance of other-directed comments, which constitute almost $90 \%$ of all metapragmatic utterances. There is also a clear trend regarding the FUNCTION of metapragmatic utterances in HYS and SPON: Taken together, roughly $70 \%$ are conflictual in nature. This coincides with the TONE of the utterances. The overwhelming majority is non-convivial. Additionally, all examples of irony and most examples of humour have a non-convivial component, and there is quite a substantial number of patronising comments, i.e., comments which are condescending to the target and which try to browbeat other posters. Many 
metapragmatic utterances are, in fact, rudeness tokens themselves, and were tagged as such in the second-order level of analysis.

Regarding the FEATURES commented on, most metapragmatic utterances are directed at the propositional content and the style of the postings. In these two categories overlaps are particularly prominent, as components of both content and style are included in the frequent metapragmatic comments on the display of hate and the lack of respect in the threads (example 16).

(16) I have never read so much vitriol and hate [...] (HYS\#355)

Obviously, even these broad trends cannot be considered to pertain to online discussions in general, as data from other studies prove. For example, Tanskanen's (2007) research on another selection of mailing-lists and message-board discussions indicates a clear preference for self-directed utterances with a collaborative purpose, guided by the participants' desire to avoid being "- in the worst-case scenario - construed as flaming" (Tanskanen 2007: 104).

\subsection{Results: Metapragmatic behaviour in contrastive perspective}

The patterns of metapragmatic behaviour differ substantially in HYS and SPON. There is a clear preference for metapragmatic comments in the German thread, which contains more than twice as many tokens (one token in 3.7 postings in SPON vs. one in 9.3 postings in HYS). The higher density of metapragmatic utterances in SPON is certainly related to the higher degree of interaction between participants, which can be seen in the ratio of participants and postings. Whereas the 880 postings in HYS were written by 801 different participants, only 124 participants posted the 754 comments in SPON. However, the use of metapragmatic utterances triggers further comments itself and is thus also partially responsible for the interactivity displayed here. Accordingly, SPON contains many more metapragmatic sequences across postings than HYS, where mostly single metapragmatic utterances are found (29 metapragmatic sequences in SPON vs. three in HYS).

The major difference between SPON and HYS lies in the category TARGET. In SPON, metapragmatic utterances are frequently directed at individual posters, who are, however, typically assigned to a particular group by the commenter. Thus, metapragmatic comments, as well as rudeness ${ }_{2}$ tokens, may involve the whole group even when negotiated with participants on an individual basis, as illustrated by (17), where the poster criticised is associated with a group of intolerant religion critics. ${ }^{5}$

(17) [Zitat von \{ \{participant_102\}\} Dem Vatikan missfällt aber Religionskritik, besonders an der christlichen Religion.] Offen gestanden, die Art von feindseliger und nach meiner Wahrnehmung ungerechter Religionskritik wie z.B. von Jemandem wie Ihnen missfällt mir auch. [...] Ich mag doch einfach nur die nicht nur bei Ihnen oft zu beobachtende Intoleranz und häufig verzerrte Darstellung zu diesem Themenbereich nicht. (SPON\#547)

\footnotetext{
${ }^{5}$ Note that the politeness marker 'Sie' as a form of address in German also indicates distance and is the dominant pronoun throughout the whole SPON-thread with 55 tokens of 'Du' and its correlates vs. 911 tokens of 'Sie' and its related forms in the 147,885 words of the entire thread.
} 
('[Quote by $\{$ \{participant_102\} $\}$ But the Vatican dislikes any criticism of religion, particularly regarding the Christian religion.] Honestly, I also dislike the kind of hostile and - in my view - unfair criticism of religion from someone like you, for example. [...] I simply do not like the intolerance and often distorted view of this topic, which can be observed not only in your behaviour.')

Structurally, the interpersonal dimension often manifests itself in the use of direct quotations, which are frequently included and immediately responded to in many postings in SPON. In this way, adjacency is reconstructed and, particularly when multiple quotations are used in one posting, the contributions gain a dialogic flavour (cf. Severinson Eklundh 2010). Despite the fact that both threads provide similar technical facilities with regard to the medium factor of quoting, this reconstruction of dialogicity, which provides a tie to individual posters, is considerably less frequent in HYS. Here, metapragmatic comments are, in the majority of cases, directed to more or less specified groups (18).

(18) Wow! I thought the typical BBC crowd only reserved such hate for Jews and GW Bush. Now we can add the Pope to the list..... (HYS\#80)

Example (18) associates the non-Catholic camp with the institutional frame of the BBC, attributing to them a particular antinormative behaviour. This is not unusual in HYS, and it is also quite common to target the BBC directly. In SPON, the system operators and the institutional frame are much less prominent in the discussion.

The most prominent FUNCTION in SPON is 'conflictual' with 75\%, and typically such metapragmatic comments contain rudeness ${ }_{2}$ tokens themselves. As pointed out before, there is also a preference for conflictual comments in HYS (although, with 58\% these are not as pronounced as in SPON), and a similar tendency for a non-convivial TONE. Example (19), directed at the non-Catholic outgroup, illustrates that even indignant comments about other posters' rudeness do not prevent the authors from being rude themselves (cf. also Smith, McLaughlin \& Osborne's findings (1997)).

(19) Why are so many of you trying to criticise the Pope pewrsonally and the rekligion he rep[resents? If you don't like our religion then please have the basic decency and manners to keep your opinions to yourselves. We don't make childish, inaccurate \& sweeping statements about you (tempting though it is, sometimers). (HYS\#31)

As regards the features commented on, in SPON there are many comments on the intellectual capacities of posters and also - and this is special for SPON - on the spelling of the postings. Such comments never occur in HYS, although the number of mistakes there is significantly higher than in SPON.

Indeed, the longest metapragmatic sequence in SPON, involving 29 postings and running through the whole thread, is concerned with orthographical errors. This metapragmatic off-topic discussion proves central to the construction of the pro- and contra-Church camps. It starts quite early in posting \#5 where one participant, who later turns out to be one of the most active pro-church advocates, criticises another participant for his misspelling of "Papst" (example 20).

(20) [Zitat ... Was hat der Pabst uns zu sagen? Nichts.]

Wenn Sie den Titel noch nicht mal schreiben können, glaube ich das gern. (SPON\#5) 
('[Quote ... What can the Pobe tell us? Nothing.] If you can't even spell the title correctly, I can well believe that.')

Here, outgroup-status is first assigned via the orthographical incompetence, and later also via the 'intellectual' incompetence of the posters taking a contra-church position. Other pro-church posters join in the debate, sharing the scorn for the contra-church advocates and thus setting up group boundaries. This is illustrated in (21), which ridicules the misspellings used by various contra-church posters, inserting them as quotations in the actual posting. This off-topic discussion is criticised by members of the contra-church group, who attribute a lack of seriousness and arguments to the prochurch group. The pro-church group constructs themselves as intellectually superior, although disadvantaged with respect to number of members.

(21) Zitat von \{\{participant_17\}\} lol. Ach, der Pabst im Watikanstaat. Und Bush in "DC", das nicht zu den USA gehört. Aha!

Nicht zu vergessen, die Sache mit dem Zitat:

\section{Zöllibat}

beim

Zitat:

Papscht

:-D (SPON\#90)

('lol. Oh well, the Pobe in the Watican. And Bush in "DC", which does not belong to the US. Aha! Not to forget the thing with the quote: cellibacy with the quote: Pophe :-D')

(German spelling errors are represented as approximate translations in bold.)

In our next section, we turn to the interplay of rudeness ${ }_{2}$ tokens and their metapragmatic evaluation.

\section{Intergroup rudeness and metapragmatic behaviour in HYS and SPON: A combined view}

In our comparison of intergroup rudeness in the two threads we now merge the secondand first-order perspectives of analysis. Figures 2 and 3 show the distribution of rudeness $_{2}$ tokens and instances of their metapragmatic negotiation across the threads, each box representing one posting. Comments containing rudeness ${ }_{2}$ tokens are marked dark grey and, in the case of multiple realisations, black. Postings with metapragmatic comments are marked red; those which are rude themselves are specially indicated by the red/grey combination. The sequence should be read from top to bottom and then from left to right. What has already been pointed out before is now aptly illustrated by the figures: The majority of metapragmatic comments are rude themselves.

Although the linear organisation of the postings in the threads masks simultaneous posting to some extent (not only for the users but also for the analyst), the figures also demonstrate that metapragmatic comments mostly tend to co-occur with rudeness $_{2}$ tokens. This suggests that rudeness 2 tokens, despite their high frequency, are still experienced as salient by many users and are therefore evaluated via metapragmatic comments of the participants from a first-order perspective, illuminating the layinterpretation of token structures as rude. 
It is important to note that Figures 2 and 3 only include those postings with metapragmatic utterances that comment on instances of intergroup rudeness. In SPON, there are 161 relevant comments, concentrated in 61 postings. In HYS, 78 such comments occurred in 51 postings. Thus, the number of postings concerned does not differ drastically, yet their distribution across the threads does. In SPON, there is a concentration of tokens in the first third of the thread, with heavy clustering between postings \#76 and \#175. Typically, these clusters indicate intense metapragmatic negotiations between two or three participants. In contrast, there is no metapragmatic comment on intergroup rudeness between postings \#552 and \#626, and only some scattered instances towards the end of the thread.

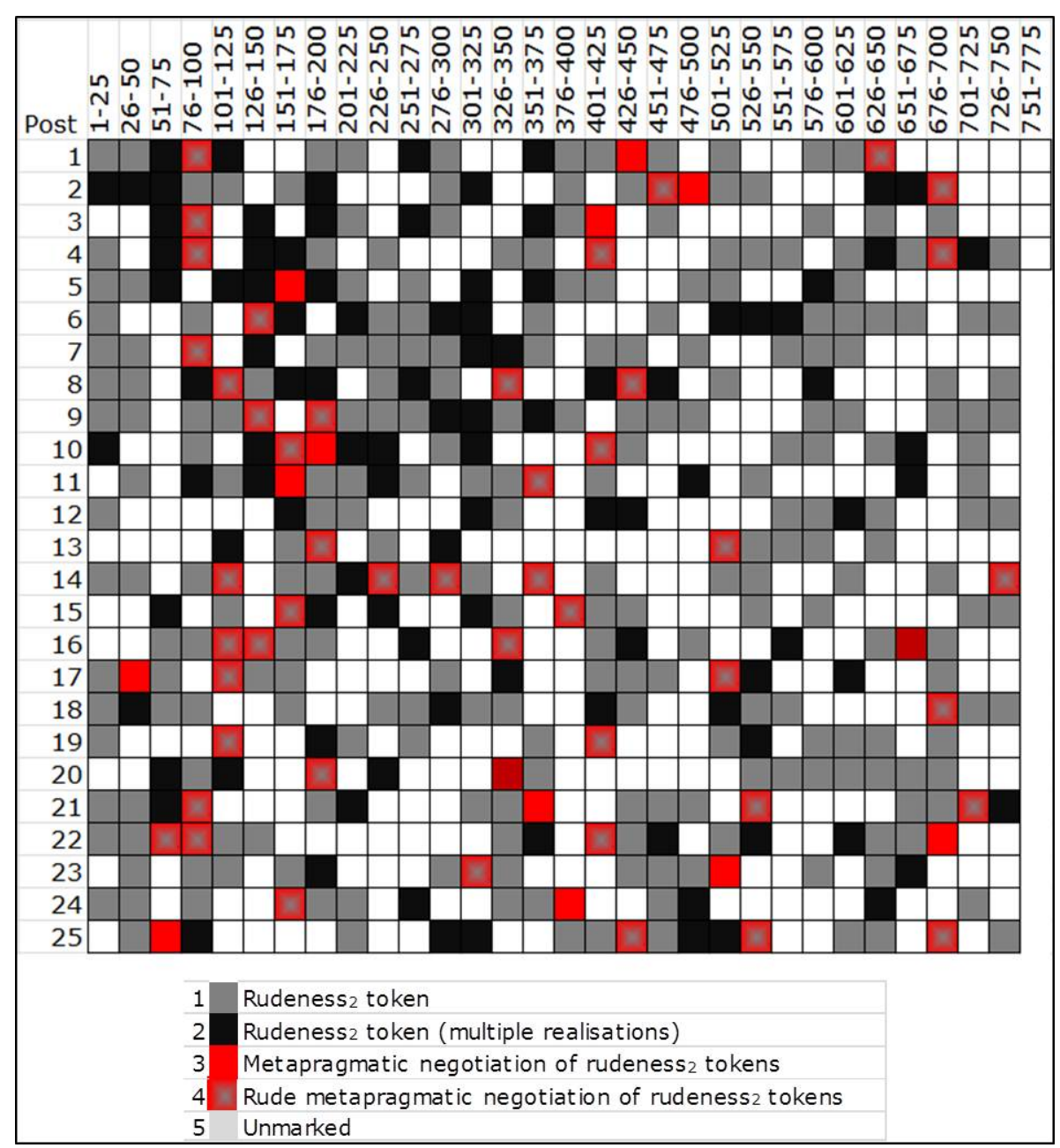

Figure 2: Distribution of postings containing rudeness 2 tokens and their metapragmatic negotiation in SPON ( $\mathrm{N}=754$ postings) 


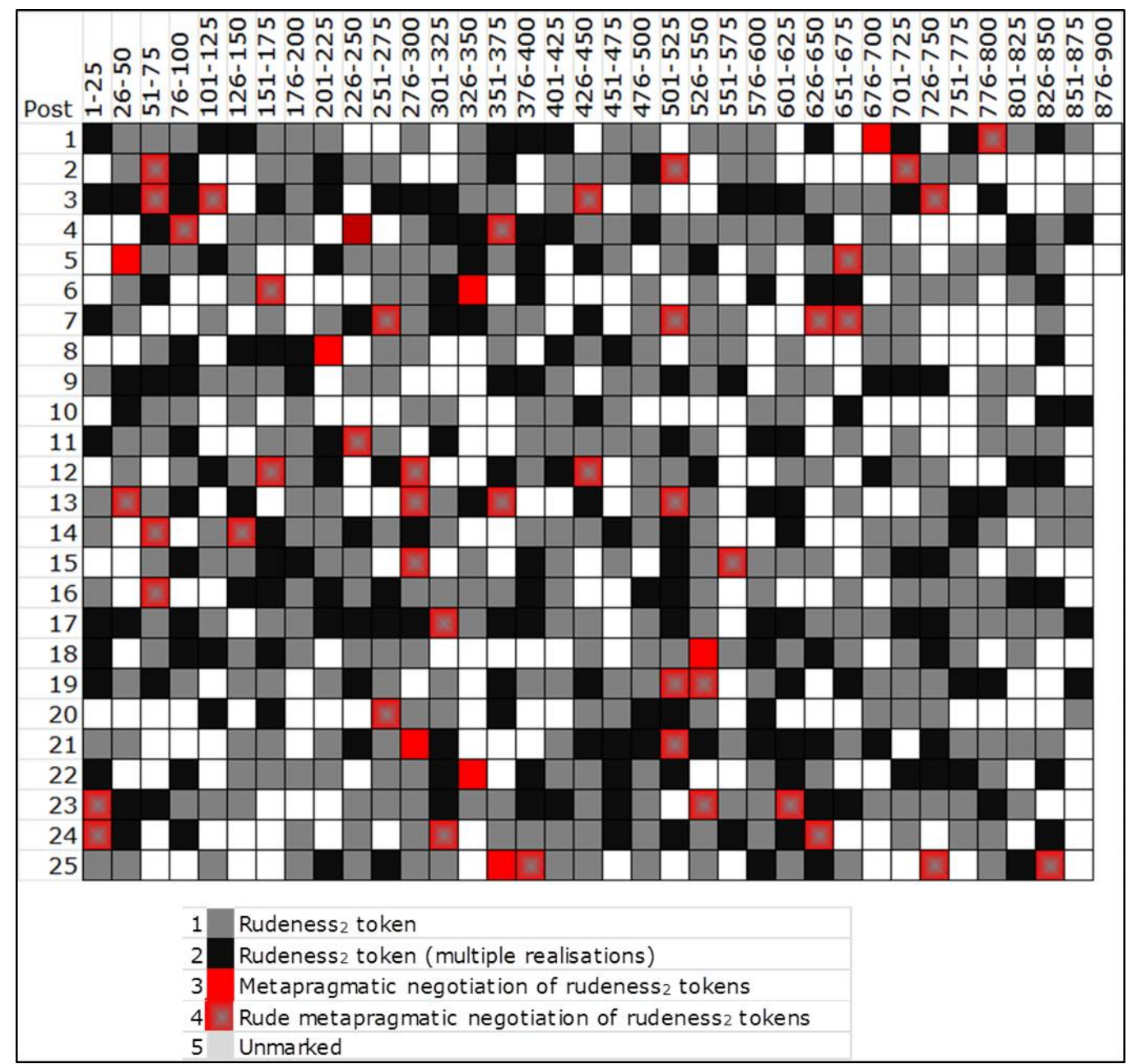

Figure 3: Distribution of postings containing rudeness 2 tokens and their metapragmatic negotiation in HYS ( $\mathrm{N}=880$ postings)

In HYS, the distribution is slightly more even. There are hardly any metapragmatic clusters. However, there is an even stronger trend for reduced metapragmatic activity in the last third of the thread. In our eyes, this pattern indicates that group construction, and with that the negotiation of norms and expectations, is nearly completed towards the end of both threads. This is aptly illustrated by the final metapragmatic comment in SPON (see (22)), which praises the improved atmosphere in the thread. Interestingly, this change is attributed by the poster to some members of his/her pro-church ingroup (SPON-participants 17 and 6).

(22) Ich empfinde es als sehr wohltuend, dass der Austausch der Meinungen zuletzt deutlich emotionsbefreiter und sachlicher geworden ist. Dies ist den Foristen zu verdanken, die eine klare sachliche (Glaubens-)Position beziehen ohne die Meinung der Anderen niederzumachen. Danke $\{$ participant_17\}\}, $\{$ participant_6\}\}, [...] (SPON\#752).

('I think it is simply wonderful that the exchange of opinions has recently gotten significantly less emotional and more factual. We can thank the forum participants for taking a clear and objective position (of belief) without trampling on the opinions of others. Thank you $\{$ participant_17\}\}, \{\{participant_6\}\}, [...]') 
As pointed out before, the absence of metapragmatic comments does not, of course, imply that rudeness ${ }_{2}$ tokens have not been experienced as rude at least by some users. It is also not always possible to assign metapragmatic comments clearly to specific rudeness tokens, especially when they are not negotiated on an interpersonal, but on an intergroup level.

\section{Conclusion}

In this study, linguistic rudeness was studied from two different research perspectives: A second-order perspective, focusing on strategies outlined in theoretical models of politeness, and a first-order perspective, considering laypersons' perceptions of token structures realised in specific contexts as rude. The combination of these two angles proved fruitful in researching communicative behaviours, and particularly intergroup rudeness, in the two forum discussions. Although the interactive practices in the two threads display some similarities, the details of how rudeness ${ }_{2}$ tokens and metapragmatic comments are distributed and negotiated are dramatically different. Our results suggest that members of HYS and SPON have each developed their own style of interaction and can thus be considered as two distinct (virtual) communities within the framework of public Internet discussion fora.

Intergroup rudeness is a common phenomenon in both threads, realised via substantial quantities of rudeness 2 tokens whose salience is frequently confirmed by metapragmatic comments. Drawing on Kienpointner's (1997) classification of intergroup rudeness, we could not only provide evidence for rudeness between hierarchical groups (which was covered in the original system) but also for intergroup rudeness displayed in the negotiation of hierarchically equal groups within the forum. This diversified range of group affiliations and constructions was catered for with the extension of the system (Tables 1 and 2).

As Figure 1 demonstrates, rudeness 2 tokens figure prominently in both threads, rendering the general atmosphere non-convivial in both fora. However, the density of rudeness $s_{2}$ tokens is much higher in HYS than in SPON. With their graphic overviews of all postings in the thread, Figures 2 and 3 show that metapragmatic negotiation tends to co-occur with rudeness $s_{2}$ tokens, which indicates that the ubiquity of rudeness 2 tokens in both threads does not automatically make them accepted behaviour.

The most notable differences between the threads are probably their degrees of interactivity and the levels on which intergroup rudeness is practiced and negotiated. The German SPON is clearly more interactive and shows a preference for rudeness and (a quite substantial amount of) metadiscourse on the interpersonal level. In contrast, posters in the English HYS tend to retreat to group levels, avoiding personal attacks and metapragmatic comments. A similar tendency has been observed in Kleinke (2012). To what extent this pattern is part of relatively stable different cultural models, abandoned only under very specific circumstances, certainly deserves further testing. What would also be valuable from a contrastive perspective is a more systematic comparison of metadiscourse on rudeness also in face-to-face interaction and, resulting from that, conventionalised impoliteness formulae in English and German. 


\section{References}

Angouri, Jo, and Theodora Tseliga (2010) "You have no idea what you are talking about!" From $e$ disagreement to e-impoliteness in two online fora. Journal of Politeness Research: Language, Behaviour, Culture 6.1: 57-82.

Bousfield, Derek (2008) Impoliteness in Interaction. Amsterdam, Philadelphia: John Benjamins Publishing Company.

Burnett, Gary, and Laurie Bonnici (2003) Beyond the FAQ. Explicit and implicit norms in Usenet newsgroups. Library \& Information Science Research 25: 333-351.

Caffi, Claudia (1998) Metapragmatics. In J.L. Mey (ed.), Concise Encyclopedia of Pragmatics. Amsterdam: Elsevier, pp. 581-586.

Culpeper, Jonathan (1996) Towards an anatomy of impoliteness. Journal of Pragmatics 25: 349-367.

Culpeper, Jonathan (2010) Conventionalised impoliteness formulae. Journal of Pragmatics 42: 32323245.

Culpeper, Jonathan (2011) Impoliteness. Using Language to Cause Offence. Cambridge: Cambridge University Press.

Danet, Brenda (2013) Flaming and linguistic impoliteness on a listserv. In S. Herring, D. Stein, and T. Virtanen (eds.), Pragmatics of Computer-mediated Communication. Berlin: Mouton de Gruyter, pp. 639664.

Der Papst in den USA - Retter in der Not? (2008) Spiegel ONLINE. Forum. Retrieved April 25, 2008, from http://forum.spiegel.de/showthread.php?t=3747.

Dresner, Eli, and Susan C. Herring (2010) Functions of the non-verbal in CMC: Emoticons and illocutionary force. Communication Theory 20: 249-268.

Dubrovsky, Vitaly J., Sara Kiesler, and Beheruz N. Sethna (1991) The equalization phenomenon: Status effects in computer-mediated and face-to-face decision-making groups. Human-Computer Interaction 6: 119-146.

Eysenbach, Gunther, and James E. Till (2001) Ethical issues in qualitative research on internet communities. BMJ 323: 1103-1105.

Graham, Sage L. (2007) Disagreeing to agree: Conflict, (im)politeness and identity in a computermediated community. Journal of Pragmatics 39: 742-759.

Haines, Russell, Jill Hough, Lan Cao, and Douglas Haines (2012) Anonymity in computer-mediated communication: More contrarian ideas with less influence. Group Decision and Negotiation, DOI 10.1007/s10726-012-9318-2.

Herring, Susan C. (2007) A faceted classification scheme for computer-mediated discourse. Language@Internet 4: article 1. Retrieved June 23, 2013, from http://www.languageatinternet.org/articles/2007/761.

Hübler, Alex, and Wolfram Bublitz (2007) Introducing metapragmatics in use. In W. Bublitz, and A. Hübler (eds.), Metapragmatics in Use. Amsterdam, Philadelphia: John Benjamins Publishing Company, pp. 1-26. 
Johnson, Mike (2010) Anonymity in online discussion forums - does it promote connections? In L. Dirckinck-Holmfeld, V. Hodgson, C. Jones, M. de Laat, D. McConnell, and T. Ryberg (eds.), Proceedings of the 7th International Conference on Networked Learning 2010. Lancaster: University of Lancaster, pp. 198-206.

Kienpointner, Manfred (1997) Varieties of rudeness. Functions of Language 4: 251-287.

Kienpointner, Manfred (2008) Impoliteness and emotional arguments. Journal of Politeness Research: Language, Behaviour, Culture 4: 243-256.

Kiesler, Sara, and Lee Sproull (1992) Group decision making and communication technology. Organizational Behavior and Human Decision Processes 52: 96-123.

Kleinke, Sonja (2007) Sprachliche Strategien verbaler Ablehnung in öffentlichen Diskussionsforen des Internets. In S.K. Herrmann, S. Krämer, and H. Kuch (eds.), Verletzende Worte. Die Grammatik sprachlicher Missachtung. Bielefeld: Peter Lang, pp. 311-336.

Kleinke, Sonja (2010) Interactive aspects of computer-mediated communication - 'Disagreement' in an English-speaking and a German-speaking Public News Group. In S. Tanskanen, L. Helasvuo, M. Johannson, and M. Raitaniemi (eds.), Discourses in Interaction. Amsterdam: John Benjamins Publishing Company, pp. 195-222.

Kleinke, Sonja (2012) Responses to rhetorical questions in English and German public news groups in the Internet. Functions of Language 19.2: 174-200.

Korenmatt, Joan, and Nancy Wyatt (1996) Group dynamics in an e-mail forum. In S. Herring (ed.), Computer-Mediated Communication. Amsterdam: John Benjamins Publishing Company, pp. 225-242.

Largier, Céline (2002) Aspekte der Debatte in argumentationsorientierten Internet-Foren: Die Abtreibungsdebatte in Frankreich und Deutschland. Deutsche Sprache 30: 287-306.

Locher, Miriam A., and Derek Bousfield (2008) Introduction: Impoliteness and power in language. In D. Bousfield, and M.A. Locher (eds.), Impoliteness in Language. Studies on its Interplay with Power in Theory and Practice. Berlin/New York: Mouton de Gruyter, pp. 1-13.

Locher, Miriam A., and Richard J. Watts (2008) Relational work and impoliteness. Negotiating norms of linguistic behaviour. In D. Bousfield, and M.A. Locher (eds.), Impoliteness in Language. Studies on its Interplay with Power in Theory and Practice. Berlin, New York: Mouton de Gruyter, pp. 77-99.

Marcoccia, Michel (2004) Online polylogues: Conversation structure and participation framework in internet newsgroups. Journal of Pragmatics 36: 115-145.

Maricic, Ibolya (2005) Face in Cyberspace: Facework, (Im)politeness and Conflict in English Discussion Groups. Växjö: Växjö University Press.

Postmes, Tom, Russell Spears, and Martin Lea (1998) Breaching or building social boundaries? SIDEeffects of computer-mediated communication. Communication Research 25: 689-715.

Postmes, Tom, Russell Spears, and Martin Lea (2000) The formation of group norms in computermediated communication. Human Communication Research 26: 341-371.

Rhea, Nancy, Alfred Rovai, Michael Ponton, Gail Derrick, and John Davis (2007) The effect of computer-mediated communication on anonymous end-of-course teaching evaluations. International Journal on E-Learning 6.4: 581-592.

Schütte, Wilfried (2000) Sprache und Kommunikationsformen in Newsgroups and Mailinglisten. In W. Kallmeyer (ed.), Sprache und neue Medien. Berlin: Mouton de Gruyter, pp. 142-178. 
Should the US give the Pope such a presidential welcome? (2008) BBC NEWS-Have Your Say. Retrieved April 20, 2008, from http://www.bbc.co.uk/news/have_your_say/

Severinson Eklundh, Kerstin (2010) To quote or not to quote: Setting the context for computer-mediated dialogues. Language@Internet 7: article 5. Retrieved June 23, 2013, from

http://www.languageatinternet.org/articles/2010/2665.

Smith, Christine B., Margaret L. McLaughlin, and Kerry K. Osborne (1997) Conduct control on Usenet. Journal of Computer-Mediated Communication 2.4. Retrieved June 23, 2013, from

http://jcmc.indiana.edu/vol2/issue4/smith.html

Spencer-Oatey, Helen (2005) (Im)politeness, face and perceptions of rapport: Unpacking their bases and interrelationships. Journal of Politeness Research: Language, Behaviour, Culture 1: 95-119.

Suler, John (2004) The online disinhibition effect. Cyber Psychology and Behavior 7: 321-326.

Tajfel, Henri (1978) Social categorization, social identity and social comparison. In H. Tajfel (ed.), Differentiation between Social Groups. Studies in the Social Psychology of Intergroup Relations. Cambridge: Academic Press, pp. 61-76.

Tanskanen, Sanna-Kaisa (2007) Metapragmatic utterances in computer-mediated interaction. In W. Bublitz, and A. Hübler (eds.), Metapragmatics in Use. Amsterdam, Philadelphia: John Benjamins Publishing Company, pp. 87-106.

Walther, Joseph B., Jeffrey F. Anderson, and David W. Park (1994) Interpersonal effects in computermediated interaction. A meta-analysis of social and antisocial communication. Communication Research 21: 460-487.

Watts, Richard J. (2003) Politeness. Cambridge: Cambridge University Press.

Watts, Richard J. (2005) Linguistic politeness research: Quo vadis? In R.J. Watts, S. Ide, and K. Ehlich (eds.), Politeness in Language. Studies in its History, Theory and Practice. Berlin, New York: Mouton de Gruyter, pp. xi-xlvii.

Watts, Richard J., Sachiko Ide, and Konrad Ehlich (eds.) (2005) Politeness in Language. Studies in its History, Theory and Practice. Berlin, New York: Mouton de Gruyter.

Weder, Mirjam (2008) Form and function of metacommunication in CMC. In S. Kelsey, and K.S. Amant (eds.), Handbook of Research on Computer Mediated Communication. Hershey, New York: Idea Group Publishing, pp. 570-586.

BIRTE BÖS is Professor of English Linguistics at the University of Duisburg-Essen. Her research interests include synchronic and diachronic pragmatics, discourse analysis and media linguistics. Together with her colleague Sonja Kleinke she conducts a research project on the communicative practices in English and German online discussion fora.

Address: University of Duisburg-Essen, Department of Anglophone Studies, R12 R04 A11, Universitätsstr. 12, 45141 Essen, Germany. E-mail: birte.boes@uni-due.de 
SONJA KLEINKE is Professor English linguistics at the English Department of Heidelberg University. She has worked in the fields of cognitive linguistics, English verb complementation, and the pragmatics of computer-mediated discourse. Her current research interests include cognitive linguistics, pragmatics, and Internet communication. She has published on English verb complementation, cognitive pragmatics, cognitive metonymy and pragmatic aspects of Internet communication.

Address: Anglistisches Seminar/Department of English, Ruprecht-Karls-Universität Heidelberg, Kettengasse 12, Room 213, 69117 Heidelberg, Germany. Email: sonja.kleinke@as.uni-heidelberg.de 